\title{
Acute Kidney Injury and Creatine Kinase Elevation After Beginning Treatment with Levetiracetam
}

\author{
Francisco-Javier Mena-Martin, Alfonso Gutierrez-Garcia, Juan-Carlos Martin-Escudero and Olga Fernandez-Arconada
}

Internal Medicine Service and Neurology Service, Hospital Universitario Río Hortega, Valladolid, Spain

DOI: https://doi.org/10.17925/ENR.2018.13.2.113

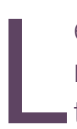

evetiracetam (LEV) is one of the most common anti-epileptic drugs available. In general, it is tolerated relatively well; the majority of adverse effects are moderate and normally occur during the initial titration. We present a patient who developed two moderately serious adverse effects after an initial LEV dose: a 28-year-old male was admitted to intensive care unit after suffering two generalised seizures, and was given $1000 \mathrm{mg}$ of LEV. Twenty-four hours after admittance, the laboratory tests showed a serum creatinine of $2.84 \mathrm{mg} / \mathrm{dL}$ and creatine kinase (CK) of $421 \mathrm{U} / \mathrm{L}$ (normal, 0-171 U/L). At all times the diuresis was normal, with a maximum value of creatinine of $4.67 \mathrm{mg} / \mathrm{dL} 48$ hours following admittance, and the CK values ranged between $421-681 \mathrm{U} / \mathrm{L}$ with proteinuria of $840 \mathrm{mg} /$ day. On the seventh day, blood tests showed a CK of 1,559 U/L and a creatinine of $1.55 \mathrm{mg} / \mathrm{dL}$. LEV was progressively substituted for lacosamide, after which creatinine, CK and albumin excretion rate were normalised. Thus, CK and renal function during treatment with LEV should be monitored, and acute kidney injury due to LEV should be considered in the differential diagnosis for any unexplained acute renal failure.

\section{Keywords}

Levetiracetam, acute kidney injury, hyperCKemia, rhabdomyolysis

Disclosures: Francisco-Javier Mena-Martin, Alfonso Gutierrez-Garcia, Juan-Carlos MartinEscudero and Olga Fernandez-Arconada have nothing to declare in relation to this article.

Review Process: Double-blind peer review.

Compliance with Ethics: All procedures were followed in accordance with the responsible committee on human experimentation and with the Helsinki Declaration of 1975 and subsequent revisions, and informed consent was received from the patient involved in this case study.

Authorship: The named authors meet the International Committee of Medical Journal Editors (ICMJE) criteria for authorship of this manuscript, take responsibility for the integrity of the work as a whole, and have given final approval for the version to be published.

open Access: This article is published under the Creative Commons Attribution Non-commercial License, which permits any non-commercial use, distribution, adaptation, and reproduction provided the original authors and source are given appropriate credit. (C) The Authors 2018.

Received: 10 June 2018

Accepted: 9 October 2018

Citation: European Neurological Review. 2018;13(2):113-5

Corresponding Author: Francisco-Javier MenaMartin, Internal Medicine Service, Hospital Universitario Río Hortega, Calle Dulzaina 2, Valladolid 47.012. Spain. E: francisco.javier.mena@hotmail.com

Support: No funding was received in the publication of this article.
Levetiracetam (LEV) is an anti-epileptic drug (AED) indicated for treatment of a broad range of seizure types, of both focal and generalised onset. ${ }^{1}$ It has many advantages that make it one of most commonly used AEDs. Among the principle ones are its high efficiency, its rapid initial effect, its availability for parenteral administration and its P450-independent metabolism. Therefore it has very few clinically significant interactions. ${ }^{2}$ In general, it is tolerated relatively well and the majority of adverse effects are moderate and normally occur during initial titration. ${ }^{2}$ We present a patient who developed two moderately serious adverse effects after initial dose.

\section{Case}

A 28-year-old male with a history of frequent cannabis use, without any previously known diseases, was admitted to the emergency room after suffering a generalised seizure. The patient got up in the morning and lifted the blind, then relatives heard a noise and found the subject had fallen on the floor with clonic movements and sialorrhea. Shortly after the arrival of the emergency services, the patient presented tongue bite, post-critical drowsiness and was transferred to our hospital. On presentation, vital signs were: blood pressure 156/98 mmHg, pulse 110 beats/minute, respiratory rate 20 breaths/minute, saturation $94 \%$ at room air and temperature $36.5^{\circ} \mathrm{C}$. Initial laboratory tests revealed a bicarbonate of $14.5 \mathrm{mEq} / \mathrm{L}$ (normal, 26-32 $\mathrm{mEq} / \mathrm{L})$ and a lactate of $13.8 \mathrm{mmol} / \mathrm{L}(0.7-2.1 \mathrm{mmol} / \mathrm{L})$, while electrolytes and other habitual parameters were normal (Table 1). Ethanol in blood was negative, toxins in urine were positive for cannabis and cranial computed tomography was normal.

In the emergency room, he presented language impairment followed by a new generalised seizure, including sphincter relaxation. The patient was given $20 \mathrm{mg}$ of diazepam and $20 \mathrm{mg}$ of midazolam, following which, he developed symptoms of psychomotor agitation. He was admitted to the intensive care unit, and LEV 1000 mg was administered intravenously every 12 hours, along with crystalloid fluid expansion with saline solution and dextrose $5 \%$. He did not suffer further seizures. A lumbar puncture was performed that showed normal parameters in cerebrospinal fluid.

At 24 hours of admission, laboratory tests revealed an increase in creatinine to $2.84 \mathrm{mg} / \mathrm{dL}$ and creatine kinase $(C K)$ of $421 \mathrm{U} / \mathrm{L}$ (normal, 0-171 U/L) with other normal blood parameters, and the following values in urine: sodium $26 \mathrm{mEq} / \mathrm{L}$, potassium $7 \mathrm{mEq} / \mathrm{L}$, creatinine $32 \mathrm{mg} / \mathrm{dL}$, normal sediment. ${ }^{3}$ Hydration therapy was maintained, and image studies, including cerebral magnetic resonance and abdominal ultrasound, revealed no significant data. The electroencephalogram (EEG) showed occasional and slow waves, and predominantly temporal bilateral sharp waves 
Table 1: Creatinine, urea, creatine kinase and proteinuria throughout the patient's hospitalisation period

\begin{tabular}{|l|l|l|l|l|l|}
\hline Time point & $\begin{array}{l}\text { Creatinine, } \\
\mathrm{mg} / \mathrm{dL}\end{array}$ & $\begin{array}{l}\text { Urea, } \\
\mathrm{mg} / \mathrm{dL}\end{array}$ & $\mathrm{CK}, \mathrm{U} / \mathrm{L}$ & Proteinuria & Treatment \\
\hline $\begin{array}{l}\text { Admission to } \\
\text { emergency } \\
\text { department }\end{array}$ & 1.07 & 36 & - & + & $\begin{array}{l}\text { Diazepam, } \\
\text { Midazolam }\end{array}$ \\
\hline $\begin{array}{l}\text { Admission to } \\
\text { intensive care unit }\end{array}$ & 0.97 & 33 & - & - & Started LEV \\
\hline Day 2 & 2.84 & 48 & 421 & - & \\
\hline Day 2 & 3.97 & 51 & 681 & - & \\
\hline Day 3 & 4.67 & 61 & - & - & \\
\hline Day 4 & 4.45 & 62 & 565 & $\begin{array}{l}840 \mathrm{mg} / \\
\text { day }\end{array}$ & \\
\hline Day 5 & 2.96 & 52 & 906 & - & \\
\hline Day 7 & 1.55 & 47 & 1559 & $\begin{array}{l}560 \mathrm{mg} / \\
\text { day }\end{array}$ & Stopped \\
\hline LEV
\end{tabular}

$C K=$ creatine kinase $; E V=$ levetiracetam .

over a discretely slow basal activity. At all times diuresis was normal, with a maximum value of creatinine of $4.67 \mathrm{mg} / \mathrm{dL} 48$ hours following admission, and CK values ranged between 421-681 U/L.

On the fourth day of hospitalisation, the patient was transferred to the Department of Internal Medicine. There was no myalgia or other symptoms and the patient was treated with 1,000 $\mathrm{mL} /$ day of saline solution, intravenous LEV 1,000 mg every 12 hours, and prophylactic subcutaneous enoxaparin. He was not receiving any nephrotoxic drugs. The patient presented a CK of $565 \mathrm{U} / \mathrm{L}$ and a creatinine of $4.45 \mathrm{mg} / \mathrm{dL}$, and a proteinuria of $840 \mathrm{mg} /$ day with normal sediment. The EEG was repeated and revealed normal bioelectric basal activity; although, with persistent occasional slow waves predominantly over the temporal posterior bilateral region, without evidence of paroxysmal anomalies.

On the seventh day blood tests showed a CK of 1,559 U/L and a creatinine of $1.55 \mathrm{mg} / \mathrm{dL}$. A pharmacological origin was suspected and LEV was progressively substituted for $100 \mathrm{mg}$ of lacosamide administered intravenously every 12 hours, after which the creatinine, the CK and the albumin excretion rate were normalised. The patient was discharged with the same oral dosage of lacosamide.

\section{Discussion}

LEV is an AED with an unknown mechanism of action, though it is suspected that it could exert its effects by interacting with SV2A protein, which is present in all synaptic vesicles; this has been linked to suppressed epilepsy seizures in animal models. ${ }^{4}$ This protein is widely expressed in the brain and it is also selectively localised in motor nerve terminals on slow muscle fibres, which could explain the association between rhabdomyolysis and LEV. ${ }^{5}$

To our knowledge, there are only three reports of LEV-induced acute kidney injury in adults; in all of which, deterioration of renal function appeared in the first few days or weeks after starting treatment with LEV and was completely resolved after stopping the drug. ${ }^{6-8}$ Moreover, the improvement in renal function in our patient was initiated before LEV withdrawal. In the case described by spengler et al. acute renal
Table 2: Levetiracetam and acute kidney injury

\begin{tabular}{|c|c|c|c|c|c|}
\hline $\begin{array}{l}\text { Year of } \\
\text { publication } \\
\text { (reference) }\end{array}$ & $\begin{array}{l}\text { Sex, age } \\
\text { (years) }\end{array}$ & Description & $\begin{array}{l}\text { Renal } \\
\text { biopsy }\end{array}$ & LEV dose & $\begin{array}{l}\text { Timeline } \\
\text { (days since } \\
\text { LEV start) }\end{array}$ \\
\hline $2009^{9}$ & $\begin{array}{l}\text { Female, } \\
17\end{array}$ & $\begin{array}{l}\text { Interstitial } \\
\text { nephritis }\end{array}$ & Yes & 250 mg BID & 10 \\
\hline $2012^{7}$ & Male, 45 & $\begin{array}{l}\text { Interstitial } \\
\text { nephritis }\end{array}$ & No & $\begin{array}{l}500 \text { mg BID } \\
\text { escalated to } \\
3,000 \mathrm{mg} / \\
\text { day }\end{array}$ & 28 \\
\hline $2012^{8}$ & $\begin{array}{l}\text { Female, } \\
69\end{array}$ & $\begin{array}{l}\text { Granulomatous } \\
\text { interstitial } \\
\text { nephritis }\end{array}$ & Yes & 500 mg BID & 14 \\
\hline $2014^{6}$ & $\begin{array}{l}\text { Female, } \\
23\end{array}$ & $\begin{array}{l}\text { Acute kidney } \\
\text { injury }\end{array}$ & No & $\begin{array}{l}\text { Load with } \\
1,000 \mathrm{mg}\end{array}$ & 1 \\
\hline $2016^{10}$ & Male, 16 & $\begin{array}{l}\text { Acute kidney } \\
\text { injury }\end{array}$ & No & $\begin{array}{l}\text { Unspecified } \\
\text { load dose }\end{array}$ & 1 \\
\hline
\end{tabular}

$B I D=$ twice daily; $L E V=$ levetiracetam.

failure with creatinine $2.76 \mathrm{mg} / \mathrm{mL}$ was observed only one day after administration of a dose of LEV of 1,000 mg in a 23-year-old woman (Table 2), with a CK peak value of 1,368; this is the only case described with both adverse effects simultaneously. ${ }^{6}$

On the other hand, Mahta et al. described the case of a 45-year-old male with low grade glioma, who developed a deterioration of renal function (creatinine $3.59 \mathrm{mg} / \mathrm{mL}$ ) without oliguria after eight weeks of treatment with progressively higher doses of LEV, up to 3,000 mg/d, which was resolved after suspending LEV. The creatinine returned to its basal value. ${ }^{6}$

Chau et al. treated a 69-year-old woman who presented severe granulomatous interstitial nephritis whose manifestations began 14 days after beginning treatment with LEV. ${ }^{8}$ There is a single paediatric case report of severe LEV-induced interstitial nephritis. ${ }^{9}$ Finally, in another case published by singh et al., a 16-year-old boy presented severe renal failure attributed by the authors to rhabdomyolysis with a CK spike of $15,111 \mathrm{U} / \mathrm{L}$; although, both adverse effects began prematurely, with a CK of $565 \mathrm{U} / \mathrm{L}$ and a creatinine of $2.20 \mathrm{mg} / \mathrm{dL} 24$ hours after beginning treatment with LEV. ${ }^{10}$

In our case, rhabdomyolysis was not the cause of deterioration of renal function, bearing in mind that it appears with CK values usually above $5,000 \mathrm{U} / \mathrm{L}$; far above those presented by the patient. ${ }^{11}$ Neither was rhabdomyolysis due to seizures, as CK-peak due to seizures is typically reached at 24-72 hours, and in the patient presented here maximum CK was observed on the seventh day of admission, without other causes of hyperCKemia (sustained immobility, seizure recurrence, ischemia, sepsis, metabolic disorders or other drugs). In a recent publication, 48 cases of LEV-induced rhabdomyolysis were reviewed, with a mean time from drug initiation of a few days. ${ }^{5}$

In six US states, there was a limited outbreak from March to December 2012 with 16 cases of acute renal failure associated with a type of synthetic cannabinoid not detected by commonly-used urine drug tests. ${ }^{12}$ However, in general, the use of cannabis is not associated with impaired renal function, so we consider such consumption as an unlikely aetiology of renal involvement in our patient. On the other hand, it is evident that cannabis was a predisposing factor for seizures. 
On the Naranjo Adverse Drug Reaction Probability Scale, ${ }^{13}$ we found LEV to be a probable factor for both rhabdomyolysis and acute renal failure. Otherwise, our patient's acute kidney injury was probably due to acute interstitial nephritis secondary to LEV, as descirbed in the above cited cases in which a renal biopsy could be performed. ${ }^{8,9}$ The possibility of deterioration of renal function due to LEV should be considered in the differential diagnosis for any unexplained acute renal failure, especially during the first few weeks of LEV administration. •
1. National Institute for Health and Clinical Excellence (NICE). Epilepsies: diagnosis and management, 2018. Available at:

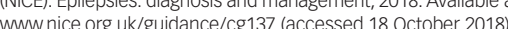

Schachter SC. Antiseizure drugs: Mechanism of Schachter SC. Antiseizure drugs: Mechanism of Available at: www.uptodate.com/contents/antiseizure-drugsmechanism-of-action-pharmacology-and-adverse-effects mechanism-of-action-ph
(accessed 22 July 2018).

3. Schumann G, Klauke R. New IFCC reference procedures for the determination of catalytic activity concentrations of five enzymes in serum: preliminary upper reference limits obtained in hospitalized subjects. Clin Chim Acta. 2003; 327:69-79

4. Lynch BA, Lambeng N, Nocka K, et al. The synaptic vesicle protein SV2A is the binding site for the antiepileptic drug levetiracetam. Proc Natl Acad Sci USA. 2004;101:9861-6

5. Carnovale C, Gentili M, Antoniazzi S, et al. Levetiracetam induced rhabdmyolysis: analysis of reports from FDA Adverse Event Reporting System database. Muscle Nerve. 2017:56:E176-8.

6. Spengler DC, Montorius GD, Hohler AD. Levetiracetam as a possible contributor to acute kidney injury. Clin Ther. 2014;36:1303-6

7. Mahta A, Kim RY, Kesari S. Levetiracetam-induced interstitial nephritis in a patient with glioma. J Clin Neurosci. 2012;19: $177-8$

8. Chau K, Yong J, I Ismail K, et al. Levetiracetam-induced severe acute granulomatous interstitial nephritis. Clin Kidney J. 2012;5:234-6.

9. Hurwitz KA, Ingulli EG, Krous HF. Levetiracetam induced interstitial nephritis and renal failure. Pediatr Neurol. 2009; 41:57-8.

10. Singh R, Patel DR, Pejka S. Rhabdomyolysis in a hospitalized 16 -year-old boy: a rarely reported underlying cause. Case Rep Pediatr. 2016;2016:7873813.

11. Huerta-Alardin AL, Varon J, Marik PE. Bench-to-bedside Huerta-Alardin AL, Varon J, Marik PE. Bench-to-bedside
review: Rhabdomyolysis - an overview for clinicians. Crit Care. review: Rhabdo

12. Centers for Disease Control and Prevention (CDC)

Acute kidney injury associated with synthetic cannabinoid use - multiple states, 2012. MMWR Morb Mortal Wkly Rep. 2013;62:93-8.

13. Naranjo CA, Busto U, Sellers EM, et al. A method for estimating the probability of adverse drug reactions. Clin Pharmacol Ther. 1981;30:239-45 